DOI https://doi.org/10.18551/rjoas.2017-12.34

\title{
PROSPECTS FOR THE DEVELOPMENT OF SINO-RUSSIAN CROSS-BORDER COOPERATION IN TOURISM
}

\author{
Gomilevskaya G.A., ${ }^{*}$ Kononov A.Y., Candidates of Economic Sciences \\ Vladivostok State University of Economics and Service, Vladivostok, Russia \\ *E-mail: gag17@yandex.ru
}

\begin{abstract}
The article provides the analysis of cross-border tourism formation in the context of SinoRussian cooperation. The causes of the tourist demand growth get determined, based on the analysis of tourist flows dynamics between Russia and China. The article uncovers preconditions for the development of cross-border tourism in Primorsky Krai, which include well-developed tourist infrastructure attractive for Chinese tourists and recreational resources, and the well-shaped regulatory framework, which reduces visa and border barriers. Based on a comprehensive study identified priority directions for the development of cross-border tourism in Primorky Territory.
\end{abstract}

\section{KEY WORDS}

Cross-border tourism, international cooperation, inbound tourism market, tourist flows, tourism objects

Subject of the article is determined by the problematic nature of cross-border tourism cooperation in itself, which requires the tourism and recreation areas to use the available resources and organizational capacity effectively and in accordance with the latest trends and market conditions.

The basic rationale for the research is to uncover the prospects for the enhancement of Sino-Russian tourism exchanges; to analyze the current initiatives in terms of their ability to raise the quality of tourist services and to attract new market segments; and to provide suggestions of how to further digest an upsurge of demand for cross-border tourism products.

Article's methodological framework is based upon the system-oriented analysis, comparison study, logical method, methods of analogy and simulation.

Cross-border tourism does get explored in certain works, including ones written and edited by Pisarevsky E.L., Zhilina L.S., Gataullina S.Y and Miheychik Y.S., Kropinova E.G. [1-4]. They to some degree define the conceptual framework, but they lack the required details which will be further described in this article.

First of all, cross-border tourism, being one of the popular areas of international cooperation, gives countries additional opportunities for the development of inbound regional tourism, for attracting investments in tourism field, for increasing the mutual tourist flows, for accessing many other benefits.

In order to promote cross-border tourism cooperation, each country takes a plethora of factors into consideration when choosing a partner. The peripheral position of Siberia and the Far East (in relation to the developed European centers) leads to the development of international relations with the Asia-Pacific region (table 1) [5-7].

Table 1 - Major tour itineraries

\begin{tabular}{|c|c|}
\hline Projects & Regions \\
\hline The great tea road & China, Mongolia, Russia \\
\hline $\begin{array}{c}\text { "East gate of Russia "Zabaikalsk-Manchuria" } \\
\text { Tourist Park }\end{array}$ & Russia, China (Autonomous region of Inner Mongolia) \\
\hline Eastern ring of Russia & $\begin{array}{c}\text { The far East and the Baikal region, Mongolia, China, Japan, } \\
\text { North Korea }\end{array}$ \\
\hline The Altai transboundary & Russia, China, Mongolia, Kazakhstan \\
\hline
\end{tabular}


Today, the North-East Asian cross-border tourism market is both the fastest growing and the largest in the world. The People's Republic of China by itself has about 130 million outbound tourists annually [9].

Geographical location of our region contributes to the development of an inter-regional tourism hub for Russian Far East in Primorsky Territory - which is the starting point for shaping tourist destinations to the Asia-Russia-Europe and Russia-Asia-Russia international corridors.

Our territory has everything required to become a key point for setting up package tours for foreign tourists to Russian Far East and to other places in Russia. Favorable climate, unique cultural and natural sites, well-developed transport infrastructure (which includes the modern airport, a network of regional airlines, marines, railways, a bus service, border checkpoints), actively developing hotel chain - it all has the most positive effect on increasing the tourists inflow from the Northeast Asian countries. In addition, our neighbors are interested in European and Russian culture. Primorye and Vladivostok are the nearest European territories for the Chinese tourists.

Over the last few years, the inbound tourism has experienced a significant increase in our region (figure 1). The inbound tourism in Primorye is increasing by more than $9 \%$ every year and domestic tourism is growing by $11-17 \%$.

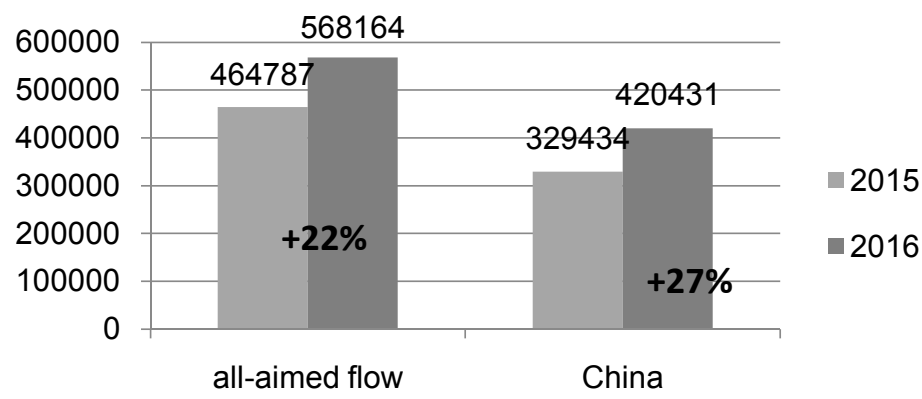

Figure 1 - Tourist flows of foreign citizens visiting Primorye, 2015-2016

Figure suggests that according to the data from Border Guard Department of FSS of Russia for Primorsky Territory, 568,000 foreigners visited our region in 2016 for all purposes of visit. The first place goes to China with 420,400 tourists ( $74 \%$ of the total number), an increase of $27 \%$ year-on-year. The trend for outbound tourism flow of Russian citizens to China is similar (figure 2).

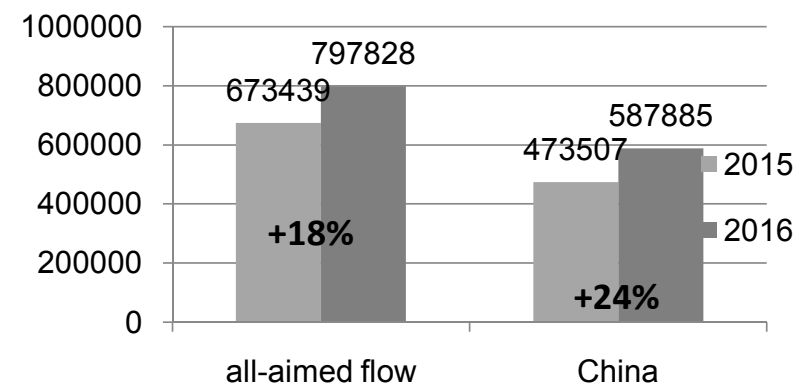

Figure 2 - Tourist flows of Russian citizens visiting China, 2015-2016

Figure shows, that the total number of Russian citizens visiting China in 2016 reached 587,000 , which is an increase of $24 \%$ year-on-year. This data clearly indicates that there is an increase of mutual tourist exchanges between two countries. Most of the international tours take place between Primorsky Territory and its neighboring Chinese provinces, namely Heilongjiang and Jilin. Most of the tours happen under the frameworks of the Agreement 
between the Government of Russian Federation and the Government of People's Republic of China on visa-free group trips.

In 2015 in the course of the cross-border tourism development, Primorsky region presented a tourist route called "Discover the Russian soul through the magic of the elements." It involves sightseeing of the tourist attractions located in the Far East region as well as in the Baikal region. These attractions are included in the "East ring of Russia" project [10]. Active promotion of the "Discover the Russian soul through the magic of the elements" tourist route allowed expanding the tours geography for Chinese tourists in Russia. Vladivostok acts as a starting point for trips from Beijing, Shanghai, Hong Kong, as well as for trips from the border towns of Chinese Jilin and Heilongjiang provinces to other Russian cities, such as Moscow, Saint Petersburg, Murmansk, Irkutsk, Novosibirsk, Chita, Ulan-Ude, Yuzhno-Sakhalinsk (Sakhalin Island).

The main reasons for the growth of inbound tourism flows are: attractive for the foreign consumers costs of tours and prices for goods in Russia; tourist attraction of newly created tourism objects, culture objects, objects of transport and tourism infrastructure; implementation of cooperation program between the regions of Russian Far East and the North-East of China; major events, which are held in the region; region's participation in prominent international tourism exhibitions and investment and trade fairs in China, such as the ones held in Harbin, Beijing, Kunming, Shanghai, as well as the participation in the tourism council of the Extended Tumangan initiative; Primorsky Territory Administration's campaign aimed at raising the awareness of the region as a tourist destination.

Today, the geographical location of Primorsky Territory forces its development as a Russia's Asian tourist hub - as the starting point for shaping tourist routes along the AsiaRussia-Europe and Russia-Asia-Russia international corridors. It meets the resources precondition, as well as the regulatory precondition for concentrating the tourist flows and allocating them further across the Russian territory.

23 foreign consulates are opened in Primorye at this point, there are also 24 border checkpoints which function internationally, among them 15 are seaports, 5 are automobile ports, 3 are railway stations, and 1 is an international airport.

Vladivostok as the capital of Primorsky Territory has established direct flights with different towns in Japan, Republic of Korea, Peoples's Repblic of China, Democratic People's Republic of Korea (Pyohgyang), Thailand and Vietnam. The number of both existing and estimated flights connecting Vladivostok and China is growing; there is also an increase in flights frequency. If in 2015 there were 16 flights a week from six Chinese cities, in 2016 we have had 22 flights a week from seven cities in China.

Tourist vessels to Japan and the Republic of Korea regularly call at Vladivostok seaport, also foreign vessels can call at the variety of ports, including Nakhodka, Vladivostok, Posyet, Zarubino, Slavyanka, port stations on Svetlaya and Olga Bays.

In July 2016, Zarubino (Khasansky district) sea port was included in the list of ports that allows visa-free entry into the territory of Russian Federation for foreign citizens and stateless people for as long as 72 hours, if they arrive on authorized ferries for the travel purposes. It will help establish the international ferry route between Sokcho (South Korea) Zarubino (Russia), as well as to revive the cross-border route from Hunchun (China), which had been highly-demanded before it was shut in 2014.

By now, the cruise ships from South Korea called "Costa Victoria" and "Sun Princess" (with the total number of passengers varying from two to five thousands each) have been calling at Vladivostok port for many years. In 2017, the total number of corresponding vessel calls for this type of cruise ships increased from 6 to 12, making the total number of cruise visitors to Vladivostok as big as 36,000 people.

Implementation of the "Free port of Vladivostok" project (with its simplified visa regime for the trips not exceeding 8 days in total) is set to contribute a great deal to the development of our region into a transitional tourist center of the Russian Far East. The Freeport territory includes 15 districts of the region. A foreigner can cross the border at any of these border points and can continue his trip across the region or the whole country. This gives us an opportunity to form complex tourist products covering the whole Russian territory [11]. 
In 2016, the Tourist Information Center of Primorsky Territory has gained an opportunity to work under the frame of "China Friendly" program. It is a widespread project, which covers a whole range of companies working in the tourism field. Project participants voluntarily go through the certification procedure, which confirms that the quality of their services meets the standards requested by Chinese travelers. This project's main goal is to increase the number of Chinese tourists visiting Russia by developing the quality of the provided services [12].

To increase the efficiency of the whole mechanism of Russia and China's cooperation development in the tourism field, the participants should: enhance the organization of joint cross-border routes; cooperate in the field of youth tourism development, in this area such projects as international camping festivals or joint quests for youth groups may be considered; develop new cruise routes for Chinese tourists, which will allow ships to call at Vladivostok seaport on their way through the Sea of Japan; support tourists visiting annual mass events held in Vladivostok, such as "Mariinsky" International Far Eastern Festival, «VRox» music festival, International "Pacific Meridian" Film Festival of Asian-Pacific countries in Vladivostok, which presented 9 movies by Chinese directors in 2017 (documentary films, feature films, musical movies, one-reelers, multiple-reel films); actively develop and implement joint educational programs, which include peer learning and practical training for the staff working in the tourism industry; exchange in advance lists of significant events, holidays, which will give a better view on the ways of life, on customs of our nations, will strengthen good-neighborly relations.

\section{CONCLUSION}

Cross-border cooperation between Russia and China in the tourism field in many ways is conducted through the mutual tourism exchanges on the Far Eastern territory. Border regions, including Primorsky Krai (which are rich with tourism and recreation resources, which develop hotel infrastructure as well as transport infrastructure, which put together helpful in terms of reducing visa and border barriers regulatory framework) show the highest numbers for tourist arrivals. Further development of border and cross-border tourism depends on expanding the range of the products in offer for such types of tourism as cultural, ethnographic, recreational, ecological, health, event tourism; it also depends on raising the quality of tourist services, on attracting new market segments, developing the cross-border brand name for "East ring of Russia" project. Sure enough, resolving aforementioned issues will have positive impact on the development of cross-border routes between Russia and China.

\section{REFERENCES}

1. Basics of tourism. Edited by E.L. Pisarevsky. Moscow: The Federal Agency for Tourism of the Russian Federation. $-375 \mathrm{p}$.

2. Zhilina L.S. Characteristics of Sino-Russian cross-border cooperation / L.S. Zhilina // Scientific research azimuth: economics and management. - 2016. - No 4. - P.159-163.

3. Gataullina S.Y Marketing of region's tourism attraction (evidence from Primorsky Territory) / S.Y. Gataullina, Y.S. Miheychik // Economics and entrepreneurship. - 2016. - No 5. P.204-208.

4. Kropinova E.G. Development of cross-border tourism and recreation regions: theoretical and practical aspects: Doctor's thesis: 25.00.24 / Kropinova E.G. - Saint Petersburg, 2017. $-324 \mathrm{p}$.

5. The meeting of XI Jinping and Vladimir Putin took place in Moscow. [Electronic resource] / Renmin Ribao. - URL: http://russian.people.com.cn/31519/8179663.html

6. Memoranda and agreements between Russia and China. [Electronic resource] / China Logist. - URL: http://chinalogist.ru/book/articles/analitika/memorandumy-i-soglasheniya-rfknr 
7. Sergunov V.V. Cultural relations between Russian Far East and China / V.V. Sergunov, I.N. Tolstykh // Methodology, methods and practices of innovations. Integration of Russian and foreign experiences in economics, project management, education, law, linguistics, culturology, ecology, zoology, chemistry, biology, medical sciences, psychology, politology, philology, philosophy, sociology, urban planning, computer sciences, engineering, mathematics, physics, history, plant growing. Collection of scientific articles on the results of the international scientific and practical conference. 2014. - P.129-135.

8. Putin and XI Jinping signed a joint statement at a meeting in Beijing. [Electronic resource] / TVC Webpage. - URL: http://www.tvc.ru/news/show/id/95147

9. Eastern ring. [Electronic resource] / Eastrussia. - URL: http://www.eastrussia.ru/material/vostochnaya_koltsevaya/

10. Experts in the tourism area showed the potential of Primorye from a different perspective at the meeting of the RTI. [Electronic resource] / NEATV. - URL: http://novostivl.ru/msg/20776.htm

11. Gomilevskaya G.A. Marine tourism as a part of "East ring of Russia" tourism brand / G.A. Gomilevskaya, G.A. Petrova // The territory of new possibilities. The Herald of Vladivostok State University of Economics and Service. - 2017. - No 3. - P.71-86.

12. Tourism Department of Primorsky Krai. [Electronic resource] / Primorsky Tourist Information Centre. - URL: http://tour.primorsky.ru/turizm 